\title{
The Problems of Mass Media Based Arabic Learning
}

\author{
Arman Husni ${ }^{1}$, Hayati $^{2}$, Rita Febrianta ${ }^{3}$ \\ \{armanhusni@gmail.com ${ }^{1}$, hayatilillah79@gmail.com ${ }^{2}$, ritaputri81@gmail.com ${ }^{3}$ \} \\ Institut Agama Islam Negeri (IAIN) Bukittinggi, Indonesia ${ }^{1,2,3}$
}

\begin{abstract}
Mass media has dominant position in sizing up opinion. The use of language in mass media often has errors such as in writing relating to the rule of imla' (dictation) writing and others, which raise misunderstanding in meaning. Besides, the process of adaptation and adoption of modern terms into arabic are done in the absence of arabic word forming rules. The mass media based arabic learning especially in Arabic newspaper still remain interesting theme to be discussed. The Language keep developing in the line with the demands of human needs. This paper is presented in order to explain the language of Arabic newspapers in learning Arabic. By getting the data of mass media growth, we understand, how much the newspaper influences the patterns of thought, attitudes and speech in society .
\end{abstract}

Keywords: mass media, Arabic newspaper, learning

\section{Introduction}

Newspaper is one of mass media which is used to convey a thought. Writing in newspaper should consider the direction of writing words or morphemes, to avoid the mistakes in typing. Although languages in the newspaper can be understood by the public, there are still many mistakes which are found in Arabic newspaper, either in terms of morphology, syntax, or semantics. Learning Language as well as Arabic relates to vocabularies, either the original or the adopted from other languages. Teachers are required to master the vocabularies adopted into Arabic and they are widely used in various mass media, whether they remains consistent with the original Arabic terms, or become the means to facilitate teaching and learning in the classroom. From the study conducted by Thu'aimah in one of teaching institution for non-speakers of Arabic language Arabic in Makkah $\mathrm{Al}$ Mukarramah, He found a disquietude that the Arabic users will get the great difficulties in using adopted vocabulary, because they have the diversity of citizens background or come from a variety of different first languages, their difficulties relate to understanding of the intercessor language ( لغة وسيطة ) in teaching [1]

Teaching and learning Arabic will keep developing and need new innovations in facing ma'rokat musthola at // war terminology. It still become question whether arabic still maintain its authenticity or it will be defeated by other existing languages in popularizing the new terms. mass media based arabic Teaching and learning especially newspaper become still interesting theme to be discussed, because socialization of new terms or vocabularies is popular via this mass media. This paper is going to present how the position of newspaper language in language learning. By having the development data of the Arabic mass media, we find that 
how big the newspaper has influenced the mindset, attitude patterns, and patterns of action of our society. With the principle of learning from something "bad", the Arabic newspaper can be used as an alternative teaching material for teachers and students in learning Arabic.

\section{Mass Media and Characteristics}

\subsection{Definition of Mass Media}

Mass Media is a tool used in delivering messages from sources to the public (recipients) by using mechanical communication tools such as newspapers, films, radio and television.[2] Mass media is a tool used in the process of delivering printed and electronic information, both in written and oral form. The examples of printed media are newspapers, magazines, newspapers, bulletins, leaflets, brochures, etc, meanwhile, the electronic mass media are radio, television, etc. The mass media contains information or news in which everyone has the right to read and know. In the mass media the involvement of language is absolute. From time to time the language is always changing or experiencing the development. The language development is also influenced the mass media itself and related language development is influenced by the mass media itself and other related elements, such as journalists, journalism, and others which are going to be discussed next.

\subsection{Characteristics of the mass media}

According to Hafied Cangara in his book "Introduction to Communication Science", the characteristics of the mass media are as follows: [2]

a. Being institutionalized, the media management involve many people from collecting, managing to presenting the information.

b. one-way communication. The communication is less possible for dialogue between the sender and receiver. If there is a reaction or feedback, it usually needs time and is delayed.

c. Being widespread and simultaneous. There is No. boundry of time and distance, because it has speed which moves broadly and simultaneously and the information conveyed is received by many people at the same time.

d. Using technical and mechanical equipment, such as radio, television, newspapers, and the similar ones.

e. Being open. The information can be accepted by anyone and anywhere without considering age, gender, and ethnic.

Then, Chaer and Agustina state that there are several characteristics of journalistic languages. They are simple, communicative, and concise. Simple mean, it is understood easily; communicative means, journalism must deliver the right information; and concise, because of space limitations (in print media) and time limitations (in electronic media) [3]

\subsection{Language errors in the language of Mass Media}

The language of the mass media or the language of journalism is the language used by journalists in writing their works in the mass media. Their writing also has different characters based on the types. The language used to write investigative reports is certainly more accurate than to those used in features one. There is also a style that is unique to write for peace journalism, as well as headlines. 
Because of the various limitations that newspapers have (space, time), the language of journalism has the unique characteristics, namely short, compact, simple, smooth, clear, straightforward, and attractive. The vocabulary used in journalistic language follows the development of language in society.

Newspapers are consumed by all level of community that have different knowledge. The language of journalism must be understood in a minimum intellectual level. Because of the condition that not all people has a time to read the newspaper, so the priority of juornalism language is to convey all information to the reader in short time by using the power of communication.

Analyzing of language used by jurnalists, many errors are found either in in grammatical, diction, or orthographic aspects. In the linguistic aspects, the highest mistakes made by journalists are in grammatical aspects and the lowest mistakes are in orthographic aspects. Based on the type of news, sports has the highest frequency of errors and the lowest ones are in criminal.

There are two factors that cause the journalists do language mistakes in their writing in newspaper. First the inside factors of jurnalist, they are: the low vocabulary mastery, the limited linguistic knowledge, less responsible in using language, forgetful habits and poor education. Meanwhile the outside factors are the limited writing time, length of work, the number of manuscripts corrected, and unavailability of language editors in newspapers.

There are some common language deviations in the mass media:

a. Morphological deviations. This deviation is often found in newspaper headlines using active sentences, namely the use of verbs. There is an unstandardized affixation removal for the verb. We often find news headlines such as; Polisi tembak mati 5 perampok nasabah bank. Israel tembak pesawat mata-mata, and Amerika bom lagi Baghdad.

b. Syntactic errors. Mistakes are in the form of incorrect use of grammar or sentence structure that often confuse understanding. This is due to poor logic. Example: Many Kasongan Handicrafts are Exported to the United States. The Title should be "Many Handicrafts of Kasongan Village are Exported to America. Similar cases are often found in both local and national newspapers.

c. Vocabulary errors. This mistake occure in the case of politeness (euphemism) or minimize the adverse effects of reporting. Example: The kidnap of Students by the Special Forces is a Bitter Pill for ABRI. The word bitter pill should be replaced by evil. In the DayakMadura conflict, it is clear that the perpetrators are Dayak and Madura, but journalists do not designate the two ethnic groups explicitly. Even in the era of the Soeharto regime a lot of vocabulary exposed was a pressing vocabulary such as GPK, subversive , intellectual actors, left and right extreme, frustrated group, anti-development group, etc. Even in the reformation era , the tendency of using bias vocabulary still occur.

d. Spelling mistakes. This error is often found in the newspaper. It also occur in writing the words, such as: Jumat is written Jum'at, khawatir : hawatir, jadwal : jadual, sinkronsingkron, antarkota : antar kota, etc.

e. Hyphenation error. The hyphenation of words still rely on the computer program that use english syllabification system which is different to Indonesian. It is suggeted to set into the Indonesian syllabification program in computer.

To avoid the mistakes above, editing of the writing materials are needed either grammar, diction or spelling. A good journalistic language are reflected in their ability to write good paragraphs. Writing the good paragraphs need the requirements how to write good sentences. Then, good paragraphs not only complete development but also show unity in content. Paragraphs become meaningless because of the insertions of supporting ideas that do 
not relate to the main idea. [4]. These errors are often occure in the language of Indonesian media, but some of them also exist in language of Arabic media.

Technology has spread to various aspects of human life, but as if it does not influent Arabic language. There is impression that it is unable to respond on the development technology which always goes hand in hand with the progress achieved by human. The science and technology is impartial to Arabic and its speakers, and make them left behind.

Then, one quirky phrase which humiliate arabic langueage accure among the people. It describes arabic as language which has no commitment for the development of the human. simply, Arabic language is not regarded as the language of intelectuals in this era, because of its limitation relate to tranformating of hundreds of knowledge needed in the future. [5]

However, from the history, we found that the "Fusa" (standard) Arabic language has ever got the great development. Linguistic and nahwu studies indicate the greatness of this language and its characteristics show the flexibility and the ability to respond the novelty in language, like the standard language of the Qur'an. The basic characteristics that exist in various forms of derivation, naht, ibdal, majaz, the ability to adopt and ta'rib which finally makes Arabic able to respond to a new phenomenon in the world of language. The freedom in terms of meaning that has no limits. In this case, Abul Fath Usman Ibnu Jinni give the example in form of qiyas, "Whatever is used as qiyas in Arabic expressions, it is from Arabic, and you have never heard it before as well as other people. Isim fa'il and maf'ul isim forms are often used, but you hear other people and make qiyas in other forms " [6]

Newspaper is one of the mass media that uses written language as its medium. Through the newspaper, the public can get current and actual information relate to events in a community, local, national, or foreign. However, by having the fact, can we say that the languages of the newspaper today have been good? The answer is "No.". There are many mistakes in the language of the newspaper, both in terms of morphology and syntax. Morphological errors are errors in the form of grammatical word formation processes, elements and types of word. While syntax errors relate to errors in the components of the sentence and its formation process. Therefore, this is very interesting to be analyzed. Although principally, we have to know that the language of newspapers is served to be consumed by the all level of community. Consequently, it has to cover all people who consume it.

\section{The Role Of Mass Media In Language Development}

The role of the mass media especially written media needs to be increased. As we know, the journalist's work/writing becomes a model for language users. The worry of Rosihan Anwar [7] who said. "journalists is the agent of language destroyers" can be avoided.

The role of the mass media is undeniable that the mass media contribute to language development. New words and terms, both originating from regional languages and foreign languages, are generally used earlier by the mass media. We do not reject that the mass media have advantages. Besides it has a large number of readers, the media has a large influence among the public. Therefore, the mass media is one of the important partners in the smooth delivery and dissemination of information about languages. Next, language development among the mass media is absolutely used to counteract information that uses words and terms that violate linguistic rules. The mass media side must be encoraged to be languages foster like us. Besides, the mass media is hoped to be able to socialize the results of language fostering and development as well as become good model for the community in using Indonesian correctly 
and well. This hope is very realistic because the press already has Guidelines for Writing Language in the Press. By having the current development of the press, many things need putting to be corcerned, especially in language ethics. Every day, blasphemy and ridicule appear in newspaper directed at officials with various problems.

\subsection{Arabic newspapers, magazines and journals in several Arab countries}

There are several newspapers in the Middle East that are referred to in various needs of the community. They are:

a. Egypt

asy-SYURUQ; Daily newspaper, has various topics. al-AHRAM; Daily newspapers contain opinions, and cultural columns

b. Iraq

al-JAZEERA; Iraqi daily newspaper, $\underline{A S H W A T} \quad$ AL-IRAQ, al-WA'YU al-ISLAMIY Magazine

c. Saudi Arabia:

al-JAZIRAH : Public Newspaper about Saudi Arabia, al-MADINAH : General Newspaper

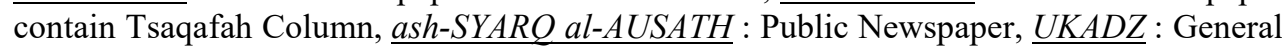
Newspaper about thaqafah column, $A L-W A T H A N$ : General Newspaper contained tsaqafah, al-AARATH : General Newspaper, UKADZ: General Newspaper contained thaqafah column, $\underline{A L-W A T H A N}$ : General Newspaper contained tsaqafah,

d. Bahrain

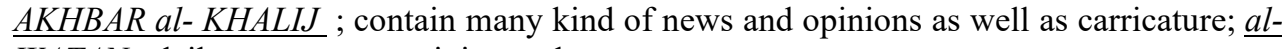
WATAN ; daily newspaper, opinion and news.

e. Yemen

al-AYYAM al-YAMANI; Yemeni news, al-MU'TAMAR Net; Opinion, Book Review, News

f. Algeria al-MIHWAR ; News, Sports, Economy. al-JUMHUR : News, Opinion, Culture. $\underline{a l-A J W A}$ 'Online : News, Opinion, Culture.

\subsection{Magazine and Arab Journals}

$A l-A D A B$; newest literary and literary news, literary and cultural revival movements in the Arab world; $A R A B I Y Y A$; The magazine is published by Saudi Arabia's ministry of culture and information; al-MAJALLAH AL-ARABIIYAH; Updating information on charity and civilization. DIWAN AL-ARAB: Pulpit of Arabic culture, thought and literature, $A L-$ MUSYAHID, Arabic Political Magazine, weekly, an-NABA; Cover; Arab Culture and Politics Magazine: al-MAJALLAH; Culture and politics magazine, DARROOB; Cultural magazine and essays, Washington $\underline{T A Q R I I R}$; The magazine contains news about washington

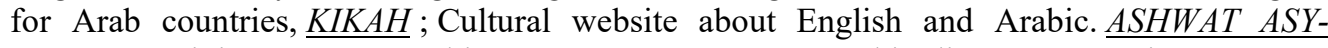
SYIMAL ; opinions, news, arabic news. $A D A B$ FANN ; Arabic literary magazines, Poetry, Stories, Cinema etc. $A L-F I K R$ AL_HURR ; Religious, Cultural Thinking, etc. $A L-A S H R$; The magazine is intended for Muslims from the aspects of culture, politics etc. in Arabic. an$\underline{N A Q I D U}$; Critical magazine Culture, politics, etc., HIRA ; Cultural Though Scientific.

Magazine. BAQIYYATULLAH; Culture, Islamic Thought. BANIPAL; Modern Arabic literary magazine. $A T-T A Q R I B$; Islamic thought. 
WORDS; The English Language Culture Magazine, ARAB SOCIETY; The latest issues of the Arab world; al-JADID ; Review of Arabic culture and art, English speaking;

ELAN MAGAZINE: Global Youth Expression Magazine including Muslim Youth, in English. $A L-J A W A D$; Islamic Sciences Magazine and Islamic discussion; JOURNAL of ARABIC and Islamic Studies, al-BALAGH; Islamic da'wah articles in the modern world in English. arabi renewal ; arabic literature. [8]

\section{Mass Media Language and Its Implementation In Learning Arabic Language}

Nowadays, one thing that makes the language of media is extraordinary is its position to be the language of daily communication for the public. It is considered as communicative interaction language to express the ideas and hope to the other easily. [9]

\subsection{The language of mass media in learning Arabic}

The great potential of the mass media cannot be denied by the world of education, especially in language education. The mass media has given nuances and linguistic atmosphere which is different from academic life. The language of media is the fact that must be respected as it is. we have been sufficient to acknowledge the role of media language and now it is the chance to have the benefit of newspaper for world of education, not only in aspect of information but also the language itself.

The language of newspapers is known as journalistic language. Parni Hadi[10] call as the language of journalism. The bad language of newspapers is a reflection of the dilapidated language of bureaucrats, because newspapers are filled by the ideas of bureaucrats. Their language is often indicated by using many acronyms, like the military which infiltrate the mass media quickly and widely. Meanwhile the language of officials has character " euphemism" which make the superficiality of meaning". Euphemism, according to Buhler's theory, is included in the appeal, which is a language that contains commands or requests addressed by the speaker to the interlocutor. Euphemism has purpose to make the other do our request or instructing [11]

The bad language of newspapers has been understood by many parties and on the other hand it becomes a legitimacy tool for journalists not to use the standard language. then, the language of the newspaper further from the standard one and create its own "community" language, with all its characteristics. Bad language in newspapers is caused by several factors. First, the source of news in the newspaper is the government official who mostly speak the language badly. This condistion will reflects in newpapers language.. Second, not all juornalists have ability to use of standard and correct language.

\subsection{Vocabulary in Arabic media}

Many vocabulary are absorbed into language of Arabic media. The nature characteristics of Arabic is not closed to the emergence of new terms due to the development of new technology. This condition give a chance to rise to new terms from a foreign languages. 


\section{Mistakes in Arabic media language}

There are two types of language errors in the Arabic language media, namely:

1- Language error

2- writing techniques errors

The language errors in the language media are as follows:

Newspapers http://www.bbc.com Accessed on 27 August 2019

\section{Title: داعش تعدم 4 ضباط شرطة بمحافظة صلاح الدين العراقية}

\begin{tabular}{|c|c|c|c|}
\hline No & $\begin{array}{l}\text { Language } \\
\text { Error }\end{array}$ & Correct & Note \\
\hline \multirow[t]{3}{*}{1} & & $\begin{array}{l}\text { Acronym form } \\
\text { of: }\end{array}$ & Which means ISIS \\
\hline & 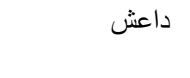 & 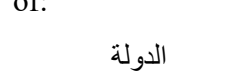 & $\begin{array}{ll}\text { Non-Arabic } & \text { is } \\
\text { difficult } & \text { to }\end{array}$ \\
\hline & & الإسلامية فى العراق & $\begin{array}{l}\text { understand the form } \\
\text { of acronyms in } \\
\text { Arabic }\end{array}$ \\
\hline 2 & إلى الثمال & 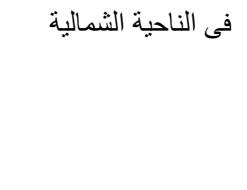 & $\begin{array}{l}\text { الثمال Expression } \\
\text { means to the } \\
\text { north, the purpose of } \\
\text { the text is to the } \\
\text { north }\end{array}$ \\
\hline 3 & 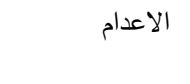 & 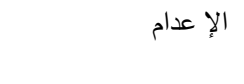 & $\begin{array}{l}\text { Writing the qat'i } \\
\text { hamzah }\end{array}$ \\
\hline 4 & 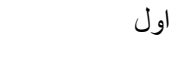 & 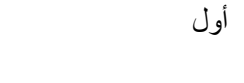 & $\begin{array}{l}\text { Writing the qat'i } \\
\text { hamzah }\end{array}$ \\
\hline 5 & الثرطة من ضابط & ثناثة ضباط الثرطة & $\begin{array}{l}\text { Does not match the } \\
\text { number of actors } \\
\text { with numbers }\end{array}$ \\
\hline 6 & الاسلامية & الإسلامبة & $\begin{array}{l}\text { Writing the qat'i } \\
\text { hamzah }\end{array}$ \\
\hline 7 & اصيب & 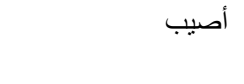 & $\begin{array}{l}\text { Writing the qat'i } \\
\text { hamzah }\end{array}$ \\
\hline \multicolumn{4}{|c|}{ Majallah مجلة المجتمع, Accessed on 27 August 2019} \\
\hline \multicolumn{4}{|c|}{ Title: المسلموط ... وظاهرة الإسلاموفوبيا } \\
\hline 9 & 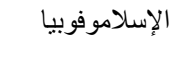 & الخوف من الإسلام الخلام & $\begin{array}{l}\text { Loanwords from } \\
\text { foreign languages }\end{array}$ \\
\hline 10 & 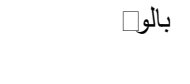 & و عاء كروي الثكل & $\begin{array}{l}\text { Loanwords from } \\
\text { foreign languages }\end{array}$ \\
\hline 11 & 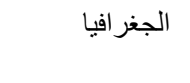 & الطبيعة & $\begin{array}{l}\text { Loanwords from } \\
\text { foreign languages }\end{array}$ \\
\hline 13 & 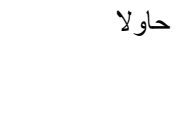 & 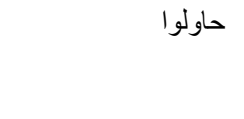 & $\begin{array}{l}\text { Not in accordance } \\
\text { with the plural of } \\
\text { words }\end{array}$ \\
\hline
\end{tabular}




\begin{tabular}{|c|c|c|c|}
\hline No & $\begin{array}{l}\text { Language } \\
\text { Error }\end{array}$ & Correct & Note \\
\hline 14 & الفيسبوك & Facebook & $\begin{array}{l}\text { Loanwords from } \\
\text { foreign languages }\end{array}$ \\
\hline 15 & التوتير & Twitter & $\begin{array}{l}\text { Loanwords from } \\
\text { foreign languages }\end{array}$ \\
\hline
\end{tabular}

Newspaper https://aawsat.com , Accessed on 27 August 2019

Title: الجامعات المصرية الخاصة تثقدم في \}بورصة العامة

بورصة 16

Loanwords from foreign languages

$17 \quad$

Loanwords from foreign languages

$18 \quad$ الأكاديمية

Loanwords from foreign languages

Mugtama.co m مجلة المجتمعAccessed 27 August 2019

Title: مقتل 11 شخصاً وتثريد المئات في انهيارات أرضية بإندونيسئ 20

$19 \quad$ تلفزيونية

Loanwords from foreign languages

20

ميكانيكية

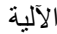

Loanwords from foreign languages

21 Al-Jazirah.net

Foreign terms should be accompanied by foreign writing

Said البلاد Sonnotatio

$\mathrm{n}$ of a wide area or country, but from the text, it means a small regional المنطقة

\section{The Mistakes In Language Of Arabic Media}

a. The adoption and adaptation of new vocabulary relating to technology and science to arabic do not apply the standard process.

b. the writing rules relate to imla' (dictation) especially mad and the choice of using alif or hamzah in imla' are often ignored

c. Transliteration of non-Arabs' names to the Arabic writing system are not compatible.

d. The use of acronym in Arabic is a new phenomenon, but without further explanation, it has pontential of misunderstanding in interpreting it.

e. The mistake in the syntactic rules. The writer/journalists have no background and knowledge relate to linguistics. Besides, the purpose of journalists to write is only to meet the target. 
f. The Mistakes in diction. the use of inapproriate words in text is going to rise the ambiguity of meaning.

g. Language of media often socializes the terms that are popular among their own community.

\section{Coonclusion}

Talking about language, humans do need language in communication. Mass media is the media used to convey a thought and idea, a newspaper is one of them. The journalist who write in newspaper have to care and consider the aspect morpheme, spelling and diction to avoid the mistakes in typing and meaning .

From the discussion above, it can be concluded that the language of mass media, especially newspapers, have often errors in rules of imla' writing which impact to the meaning. Then, the process of adoption and adaptation new term into arabics run with the absence of considering the rules of arabics transiliteration.

As for learning, the terms that appear in the language of the newspaper should be tried to use terms that are in accordance with the character of the Arabic language, thereby reducing the occurrence of Arabic vocabulary extinction.

\section{References}

[1] Rusydi Ahmad Thuaimah, Ta'limul Lughah Arabiyah lighairin Natiqin biha Manahijuhu wa Asalibuhu. Ribath: ISESCO, 1989.

[2] Hafied Cangara, Pengantar Ilmu Komunikasi. Jakarta: Rajawali Press, 2008.

[3] L. A. Abdul Chaer, Sosiolinguistik, Perkenalan Awal. Jakarta: Rineka Cipta, 1995.

[4] Suroso, "Pemanfaatan Ragam Bahasa Jurnalistik Di Media Massa," uny, 2018. [Online]. Available: http://staff.uny.ac.id/sites/default/files/pengabdian/dr-suroso-mpd-mth/ppm-suroso-bahasajurnalistik.pdf.

[5] Mahmud Ahmad As-Said, Syu'un Lughawiah. Damascus: Darul Fikr, 1979.

[6] Abul Fath Usman Ibn Jinni, Al Khashois, I. Cairo: Darul Kutub Al-Misriah, 2006.

[7] Rosihan Anwar, Bahasa Jurnalistik Indonesia dan Komposisi. Media Abadi, 2004.

[8] "koran arab." [Online]. Available: https://iastudies.wordpress.com/download/koran-arab/.

[9] A. G. A. Azmi, "Lughatus Shohafah wa Salamatul Lughah," J. Arab. Shohafah, 1997.

[10] Republika, "Bahasa Koran yang Direndahkan," 2018. .

[11] Ignas Kleden, Eufimisme Bahasa, Konsensus Sosial, dan Kreativitas. Kata Prisma, 1997. 